日植病報 $54: 189-197$ (1988)

Ann. Phytopath. Soc. Japan 54: 189-197 (1988)

\title{
チャ，野菜およびモクレンから分離した水核活性細菌の 分類学的研究
}

\author{
後藤 正夫*・黄 奔 立*・牧野 孝宏** \\ 後藤 孝雄***・稲葉 忠興***

\begin{abstract}
Masao Goto*, Ben Li HuanG*, Takahiro Makino**, Takao Goto*** and
Tadaoki INABA***: A Taxonomic Study on Ice Nucleation-Active Bacteria

Isolated from Gemmisphere of Tea (Thea sinensis L.), Phyllosphere of

Vegetables, and Flowers of Magnolia denudata Desr.
\end{abstract}

\begin{abstract}
The ice nucleation-active bacteria (INAB) isolated from gemmisphere of tea plants belonged to three genera; Erwinia (23 strains), Xanthomonas (44 strains), and Pseudomonas (1 strain). The strains of Erwinia isolated from tea fields in Shizuoka prefecture in 1978-1980, and in Kagawa pref. in 1987 were identified as $E$. ananas. An ice nucleation-active xanthomonad detected with a high frequency in Shizuoka pref. and Tokushima pref. in 1986-1987 was, however, identified as a strain of $X$. campestris from morphological, physiological, and biochemical traits. The bacterium was also found on some vegetables in Shizuoka pref. with a low frequency, but it was not pathogenic to any carrier plants from which it was isolated. The taxonomic affiliation of this bacterium was left for future study, although the new subspecific rank was suggested to be more eligible than the pathovar rank. The strains of INAB isolated from flowers of Magnolia denudata and leaves of various vegetables in Shizuoka pref. and a strain isolated from tea gemmisphere in Kagawa pref. were identified as $P$. syringae. Although they were identical either with $P$. syringae pv. delphinium (17 strains) or $P$. syringae pv. syringae (1 strain) in biochemical tests, all strains were not pathogenic to any carrier plants and Delphinium spp. as well. However, all of six strains that were arbitrarily selected, formed water-soaked lesions on the leaves of lilac (Syringa vulgaris $\mathrm{L}$.) through stomata and wounds. Therefore, these strains were identified as $P$. syringae pv. syringae. A strain of INAB isolated from Wasabi petiole was a non-fluorescent pseudomonad with positive tobacco HR. Although the diagnostic traits of the bacterium were similar to those of $P$. cichorii, it showed no pathogenicity to any plants tested including Wasabi and lettuce. Therefore, its taxonomic affiliation was left for future study. All INAB mentioned above showed the type $\mathrm{A}$ ice nucleation-activity, i.e. the supercooling temperature was between -2.8 and $-3 \mathrm{C}$ except for the Wasabi pseudomonad at -4 and $-5 \mathrm{C}$.
\end{abstract}

(Received January 1, 1988)

Key words: ice nucleation-active bacteria, taxonomy.

1970 年代のはじめに，水滴を $-2 \sim-3 \mathrm{C}$ で結水す る水核活性細菌(Ice nucleation-active bacteria; INAB) の存在が発見された。INAB は Pseudomonas syringae
など葉面居住性の高い細蔺に多くみられることから， 凍霜害の原因としての役割が研究され，曟薬や遺伝子 組換え細菌を用いた防霜の可能性が娭討されてき

* 静岡大学農学部 Faculty of Agriculture, Shizuoka University, 836, Ohya, Shizuoka 422, Japan

** 静岡県農業試験場 Shizuoka Agricultural Experiment Station, 678-1, Tomigaoka, Toyoda-cho, Iwata-gun, Shizuoka 438, Japan

*** 四国農業試験場 Shikoku Agricultural Experiment Station, Zentsuji, Kagawa 765, Japan 
た ${ }^{-623,38)}$ 。最近はさらに人工罡や食品工学等への利用 も研究され，その重要性が広く注目されるよらになっ てきた。

INAB の植物凍霜害への関りは，その斬新な発想か ら植物病理学領域のみでなく, 栽培学, 気象学, 工学, 応用微生物学等, 幅広い領域で活発な研究が続けられ ている。しかし涷霜害に占める INAB の役割につい ては評価が分かれ，必ずしも結論に達していないのが 現状である。これはおもに涷霜害発生時の INAB の 生息密度がつねに高いとは限らないこと ${ }^{14,153}$, 植物自 身がもつ氷核活性物質を無視できないとする植物生理 学者らの指摘 ${ }^{1,2)}$ に反諭するに足る十分な INAB の生 態的資料が得られていないことに基因するい。

今日，水核活性を孔つ細菌としてはP. syringae の ほか, Erwinia herbicola ${ }^{24,35)}, P$. viridiflava $a^{30,33)}$, $P$. fluorescens ${ }^{16,22,31)}$ および Xanthomonas campestris ${ }^{12,18,29)}$ 等が知られている。しかしそれぞれの種 (species) のなかに占める INAB 系統の割合や，それ
らの植物親和性および生態なと，凍霜害の原因として 欠くことのできない各種要因についてはまだ不明の点 が多く残されている。

著者らは凍霜害に対する INAB の役割を正しく把 握するため, チャ打よび野菜の実験系を使って研究を 進めつつある。本報告はおるにこれらの植物から分離 した INAB の分類学的研究の結果をとりまとめたも のである。

\section{材料および方法}

供試細菌 供試細菌の来歴を Table 1 に示した。こ れら INAB の分離は，野菜の葉およびモクレンの花 では約 $1 \mathrm{~g}$ の組織片を隇菌水 $10 \mathrm{ml}$ 中に入れて十分 攪䢁して洗い，洗液を適宜希积したのち普通寒天平板 に塗抹培養した。萌芽前のチャ芽は 1 芽を $10 \mathrm{ml}$ 滅菌 水中で磨砕し，葉が展開した芽では野菜と同じ方法で 得た洗液を希积後平板培養した。ワサビから分雒した No. 54 菌株は，ワサビ葉柄の褐色壊死部から植物病

Table 1. Bacteria used in the studya )

\begin{tabular}{|c|c|c|c|c|}
\hline Code number & $\begin{array}{l}\text { No. of } \\
\text { strain }\end{array}$ & Plant and plant part & Locality & $\begin{array}{l}\text { Isolator and year of } \\
\text { isolation }\end{array}$ \\
\hline $1-20,53$ & 21 & Tea (Thea sinensis L.); bud & Shizuoka & Goto, M., 1986-1987 \\
\hline IN1-10, 12, 13, 15 & 13 & Tea (Thea sinensis L.); bud & Shizuoka & Makino, 1978-198025,263 \\
\hline $\begin{array}{l}8703,8704,8707- \\
8712,8717\end{array}$ & 9 & Tea (Thea sinensis L.); bud & Kagawa & $\begin{array}{l}\text { Goto, T. \& Inaba, } \\
1987\end{array}$ \\
\hline $8738-8751$ & 14 & Tea (Thea sinensis L.); bud & Tokushima & $\begin{array}{l}\text { Goto, T. \& Inaba, } \\
1987\end{array}$ \\
\hline $49-51$ & 3 & Magnolia denudata Desr.; bud & Shizuoka & Huang, 1987 \\
\hline 23 & 1 & $\begin{array}{l}\text { Cabbage (Brassica olerasea L. var. capitata } \\
\text { L.); leaves }\end{array}$ & Shizuoka & Goto, M., 1987 \\
\hline 47 & 1 & $\begin{array}{l}\text { Cauliflower (B. oleracea L. var. botrytis } \\
\text { L.); leaves }\end{array}$ & Shizuoka & Huang, 1987 \\
\hline 52 & 1 & $\begin{array}{l}\text { Chinese cabbage (B. pekinensis Rupr.); } \\
\text { leaves }\end{array}$ & Shizuoka & Huang, 1987 \\
\hline $35-44$ & 10 & Chinese mustard (B. chinensis L.); leaves & Shizuoka & Huang, 1987 \\
\hline $22,45,46$ & 3 & $\begin{array}{l}\text { Turnip ( } B . \text { rapa } \text { L. var. glabra Kitamura); } \\
\text { leaves }\end{array}$ & Shizuoka & Goto \& Huang, 1987 \\
\hline 48 & 1 & $\begin{array}{l}\text { Japanese radish (Raphanus sativus } \text { L. var. } \\
\text { acanthiformis Makino); leaves }\end{array}$ & Shizuoka & Huang, 1987 \\
\hline 54 & 1 & Wasabi (Eutrema wasabi Maxim.); petioles & Shizuoka & Goto, M., 1987 \\
\hline 21 & 1 & Lettuce (Lactuca sativa $\mathrm{L}$. ); leaves & Shizuoka & Goto, M., 1987 \\
\hline 24 & 1 & Spinach (Spinacia oleracea L.); leaves & Shizuoka & Goto, M., 1987 \\
\hline 55 & 1 & Corn (Zea mays L.); leaves & Shizuoka & Takikawa, 1985 \\
\hline TC1-TC6 ${ }^{\mathrm{b})}$ & 6 & Tea (Thea sinensis L.); leaves & Kagoshima & Uehara et al. \\
\hline Camp B, Ec) & 2 & $\begin{array}{l}\text { Cabbage (B. oleracea. var. capitata } \mathrm{L} .) \text {; } \\
\text { leaves }\end{array}$ & Shizuoka & Goto, M., 1964 \\
\hline
\end{tabular}

a) Pathovars of Xanthomonas campestris tested for the ice nucleation activity include: pv. begoniae; pv. campestris; pv. cerealis; pv. citri; pv. cucurbitae; pv. glycines; pv. nigromaculans; pv. oryzae; pv. phaseoli; pv. phormiicola; pv. physalidicola; pv. pruni; pv. tardicrescens; pv. vesicatoria; and pv. vitians.

b) $X$. campestris pv. theicola, the causal agent of bacterial canker of tea ${ }^{5,391}$.

c) $X$. campestris pv. campestris. 
原細菌と同じ方法で分離した。平板培地上に発育した 集落のすべてについて，次に述べる方法で氷核活性を 調べ，陽性の菌株を供試細菌とした。

水核活性の测定法 クールエース（東京理化侏) を 用いてィタノールを泠却しこの上にパラフィン・キ シロール混液 ${ }^{24)}$ を噴霧したアルミ箔を浮かへ，サーミ スター（宝工業侏）で表面温度を－5Cに設定した。 この上に, 普通寒天斜面培盖 (28 C, 24 48 h) から 調製した細菌懸濁液（濃度䄪 $10^{8}$ 細菌 $/ \mathrm{ml}$ )を $10 \mu \mathrm{l}$ つ 10 滴落し， 30 秒以内に $100 \%$ 結水するるのを水核 活性陽性 (Type A) と判定した。

細菌培美の保存 米核活性を確認した菌株について は，馬鈴薯・ブドウ糖寒天および普通寒天培地を用い

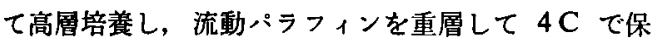
存するとともに, 一部は凍結乾燥して保存した。

病原性 鉢植えで育苗した植物に噴䨒接種および有 倁接種し，24 時間湿室に保ったのちガラス室に移して 発病の有無を観察した。

細菌学的性贸 ポリー $\beta$-ヒドロキシ酪酸顆粒の検出 はスダンブラック $\mathbf{B}$ 染色法 ${ }^{362}$ で，また鞭毛染色は変法 山中氏法37によった。オキシダーゼ，カタラーゼ，丁 ミラーゼ,ウレアーゼ,アミ，酸脱炭酸醭素の諸反応， 硝酸塩還元性およびアセトイン，2-ケトグルコン酸， インドール生成はCowanの方法 ${ }^{8}$ により，また $\mathrm{H}_{2} \mathrm{~S}$ 生成は同 3 によって調べた。フェニルアラニンデア ミナーゼおよびフォスファターゼ反応はそれそれれ

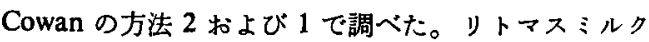

反応，せラチン溶解性，メチルレット反応，KCNに 上る生育阻害, グルコース酸化・発醉陚験およびエス クリン, カゼイン, Tween 80 の加水分解性む同寒験 書によった。唯一の炭妻源扣よび窒素源としてのアス パラギンの利用性扐よび食塩耐性は Dye $\mathrm{e}^{92}$ の方法によ った。アルギニンジヒドロラーゼ, 扎よび蕉糖からの 還元物質の生成は Schaad $^{36)}$ の方法によった。レシチ ナーゼ反応はオクソイド即黄淮 (Oxoid Ltd.) を 10\% 添加した普通寒天培地を用いて調べた。炭素源の利用 性は, Xanthomonas および Pseudomonas 属細菌では ブロモチモル青を加えた Ayers ら ${ }^{34)}$ の合成培地を, Erwinia 属細菌ではブロモクレソール紫を加えた $1 \%$ ペプトン水を基本培地とし，1\%の炭素源を加えて調 ベた21”。有機酸の利用性はDye 9 の OY 培地を用い, ペクチンゲルの液化は Paton ${ }^{322}$ の培地を用いた。蛍 光色素の生成は King B 培地19)で調べた。

ユビキノンの同定 Collins7)の方法によった。

DNA の GC 比率 DNA の分㪐は Marmur ${ }^{27)}$ の方 法により，また GC 含量はギルホード 250 分光光度計 で，Escherichia coli K-12 株の DNA を標準に測定し た $T_{\mathrm{m}}$ 值から Marmurおよび Doty28) の式によって 算出した。

\section{結果}

細菌学的性質から，チャ，野菜技よびモクレンから 分離した INAB は, Xanthomonas, Pseudomonas およ び Erwiniaのいずれかに入ることが明らかとなった。

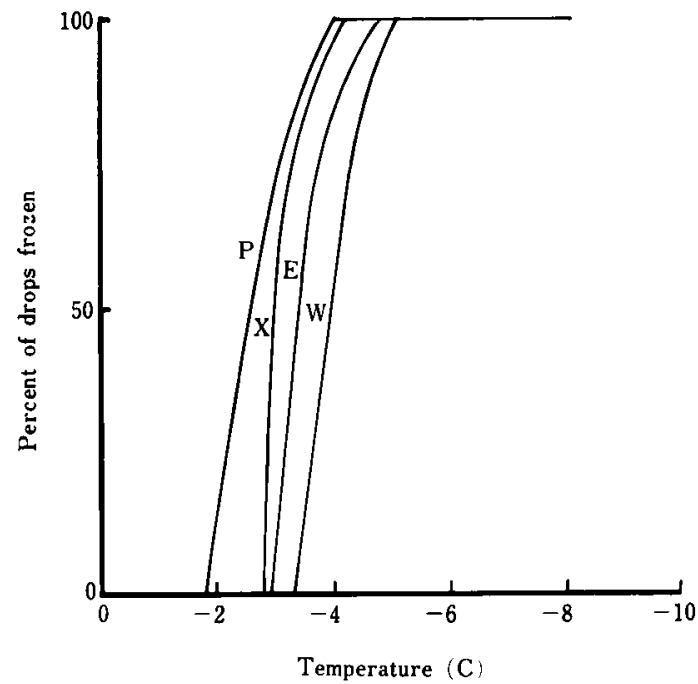

Fig. 1. Ice nucleation spectra of Pseudomonas syringae, Erwinia ananas, Xanthomonas campestris and a pseudomonad from Wasabi. P-strain No. 42, X-strain No. 1, E-strain No. 53 and W-strain 54. 


\section{Xanthomonas 属細菌}

1986 年および 1987 年に静岡紧および徳島県の茶園 で採集したチャ芽から分離されたINAB は，茶園の いかんを問わず，大部分がこの細菌で，Pseudomonas 拉よび Erwinia 属細菌がそれぞれ1例分離されたにす ぎなかった。本菌はチャ以外では，静岡県下のレタス， カブ,カンランおよびホウレンソウから 1986 年秋に それぞれ 1 例ずつ分㓲隹されたのみで，その自然分布は チャ芽に特異的に高いことが明らかとなった。本菌の 氷核活性は Fig. 1 に示すと㧍りで，P. syringae のそ

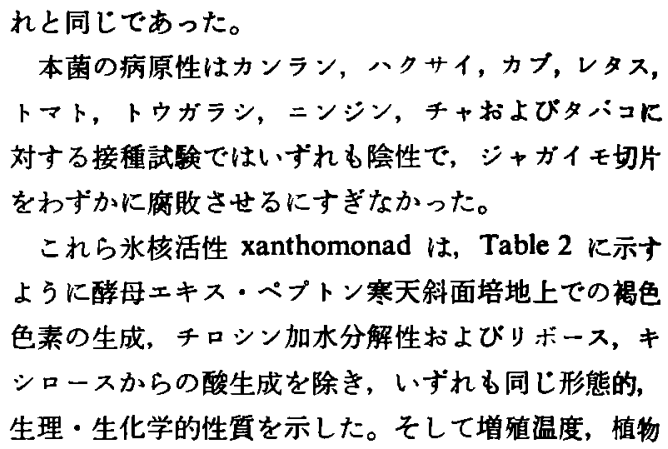

Table 2. Comparison of the bacteriological characteristics among the ice nucleation-active xanthomonad, $X$. campestris pv. campestris and pv. theicola

\begin{tabular}{|c|c|c|c|}
\hline Characteristics ${ }^{a}$ & INAX ${ }^{\mathbf{b})}$ & $\mathrm{XCC}$ & $\mathrm{XCT}$ \\
\hline Growth on YP agar plate & slow & moderate & slow \\
\hline Growth factor requirement & $-c)$ & - & + \\
\hline Growth temperature (C): minimum & 10 & 7 & 7 \\
\hline optimum & 33.5 & $28-30$ & $28-30$ \\
\hline maximum & $42-43$ & $37-88$ & 35 \\
\hline Hydrolysis of : tyrosine & D & + & - \\
\hline gelatin & + & + & - \\
\hline Levan formation on : YPAd & - & + & - \\
\hline Phenylalanine deaminase & + & + & - \\
\hline Lecithinase & + & + & - \\
\hline Pectin liquefaction & D & + & - \\
\hline Litmus milk reaction & $B, D, C, P e)$ & $\mathrm{B}, \mathrm{D}, \mathrm{C}, \mathrm{P}$ & - \\
\hline $\begin{array}{l}\text { Acid from ribose, melibiose, lactose, maltose, raffinose, } \\
\text { sucrose, salicin, erythritol, } \alpha \text {-methylglucoside, glycogen }\end{array}$ & + & + & - \\
\hline Acid from sorbitol, melezitose & + & + & - \\
\hline Mol $\%$ of DNA & 67.9 & & nt $f$ \\
\hline Ubiquinone & Q8 & Q8 & nt \\
\hline Potato rot & + & + & - \\
\hline Pathogenicity to tea & - & - & + \\
\hline
\end{tabular}

a) All bacteria were positive for: rods measuring $0.4-0.7 \times 0.7-2.1 \mu \mathrm{m}$; motility by a polar flagellum; Onidative metabolism of glucose; production of catalase, oxidase (weak), phosphatase, DNase and $\mathrm{H}_{2} \mathrm{~S}$; tolerance to $4-5 \% \mathrm{NaCl}$; hydrolysis of esculin, Tween 80, starch, casein; ONPG; acid from xylose, L-arabinose, glucose, fructose, mannose, cellobiose and trehalose; and use of formate, acetate, malate, citrate, fumarate, tartrate, malonate, oxalate, mesaconate, saccharate, mucate, propionate, quinate, anthranilate, glycolate, butyrate and sebacate.

All bacteria were negative for: Gram reaction; accumulation of poly- $\beta$-hydroxybutyrate; spore-formation; production of fluorescent pigment, acetoin, indole, 3-ketolactose, reducing substances from sucrose, urease, arginine dihydrolase, amino acid decarboxylases; gluconate test; methyl red test; nitrate reduction; denitrification; use of asparagine as a sole source of $\mathrm{N}$ and $\mathrm{C}$; growth in $0.1 \%$ TTC and $0.075 \% \mathrm{KCN}$; acid from rhamnose, inositol, adonitol, dulcitol and inulin; use of caprate, $p$ aminobenzoate; and tobacco hypersensitivity reaction.

b) INAX: ice nucleation-active xanthomonad, strains No. 1-24; XCC: $X$. campestris pv. campestris, strains Camp B, E; XCT: $X$. campestris pv. theicola, strains TC1-TC6.

c) $+: 80 \%$ or more of strains positive; $-: 80 \%$ or more strains negative; $\mathrm{D}:$ varied by strains.

d) YPA: yeast-extract peptone agar.

e) B : blue; D: decolorization; C: curd formation; P: peptonization.

f) nt: not tested. 
に対する病原性，氷核活性扰よびソルビトール利用性 を除き，X. campestris pv. campestris に一致した。本 菌は発育が達く，集落は透明，非粘液性で，チャかい 上5病菌 X. campestris pv. theicola ${ }^{5,39)}$ に類似してい
たか，両菌は氷核活性，細菌学的性質および病原性で 明確に区別された。

\section{Pseudomonas 属細菌}

野菜類およびモクレンの花から分離した大部分の

Table 3. Bacteriological characteristics of the ice nucleation-active pseudomonads

\begin{tabular}{|c|c|c|c|c|}
\hline \multirow{2}{*}{ Characteristicsa) } & \multicolumn{4}{|c|}{ Strains } \\
\hline & 41 & $\begin{array}{l}35-40,42 \\
45,46,48\end{array}$ & $\begin{array}{l}43,44,47 \\
49-52,8717\end{array}$ & 54 \\
\hline Fluorescent pigment on $\mathrm{KB}$ & $+b)$ & + & + & - \\
\hline Oxidase & - & - & - & + \\
\hline Phosphatase & - & $\mathrm{D}$ & D & + \\
\hline DNase & - & D & - & - \\
\hline Gelatin liquefaction & + & + & + & -- \\
\hline Urease & + & + & + & - \\
\hline Litmus milk & BDP & BDP & BDP & $B$ \\
\hline Tyrosinase & + & + & - & - \\
\hline Hydrolysis of: Tween 80 & + & + & + & - \\
\hline starch & + & + & + & - \\
\hline esculin & + & + & + & - \\
\hline casein & + & + & + & - \\
\hline ONPG & - & - & - & - \\
\hline Use of asparagine as $\mathrm{N}$ and $\mathrm{C}$ & + & + & + & - \\
\hline Growth at $35 \mathrm{C}$ & + & + & + & - \\
\hline Levan formation & + & - & - & - \\
\hline Pectate liquefaction & - & + & - & - \\
\hline Red. substances from sucrose & + & + & + & - \\
\hline $\mathrm{NaCl}$ tolerance: $\max . \%$ & 4 & $3-4$ & $3-4$ & 5 \\
\hline Acid from: L-arabinose & + & + & + & - \\
\hline xylose & + & + & + & - \\
\hline sucrose & + & + & + & - \\
\hline sorbitol & + & + & + & - \\
\hline inositol & + & + & + & - \\
\hline erithrytol & + & + & + & - \\
\hline adonitol & + & + & - & - \\
\hline D-arabinose & + & + & - & - \\
\hline raffinose & - & - & - & + \\
\hline galactose & + & + & + & - \\
\hline cellobiose & + & + & + & + \\
\hline ribose & + & + & + & - \\
\hline melibiose & + & + & + & - \\
\hline citrate & + & + & + & + \\
\hline benzoate & + & + & + & - \\
\hline
\end{tabular}

a) All strains were positive: motility by $1-4$ polar flagella; aerobic growth; oxidative metabolism of glucose; production of catalase and urease; growth inhibition by $\mathrm{KCN}$; growth at $4 \mathrm{C}$; acid from glucose, fructose and mannose; utilization of malonate, succinate, malate, acetate, propionate and tartrate; and tobacco hypersensitivity reaction.

All strains were negative: Gram reaction; poly- $\beta$-hydroxybutyrate accumulation; spore formation; production of amino acid decarboxylases, arginine dihydrolase, lecithinase, phenylalanine deaminase, $\mathrm{H}_{2} \mathrm{~S}$, 3-ketolactose, indole and acetoin; gluconate test; nitrate reduction; denitrification; methyl red test; utilization of trehalose, rhamnose, maltose, lactose, salicin, a-methylglucoside, dulcitol, melezitose, inulin, glycogen and xylan; and potato rot.

b) For symbols, see Table 2 . 
Table 4. Comparison of the differential characteristics of the ice nucleation-active pseudomonads to those of Pseudomonas syringae pv. syringae and pv. delphinium

\begin{tabular}{|c|c|c|c|c|c|c|c|c|c|c|c|}
\hline \multirow{2}{*}{ Bacteria } & \multicolumn{11}{|c|}{ Characteristics ${ }^{a}$ ) } \\
\hline & L. & $\mathrm{O}$ & $\mathbf{P}$ & A & $\mathrm{T}$ & $\begin{array}{l}\text { 2-keto- } \\
\text { gluconate }\end{array}$ & $\mathrm{KNO}_{3}$ & sucrose & gelatin & esculin & tyrosine \\
\hline P. syringae pv. syringae & + & - & - & - & + & - & - & + & + &,$+ v$ & $\mathbf{v}$ \\
\hline P. syringae pv. delphinium & - & - & - & - & + & - & - & + &,$+ \mathrm{v}$ & $\mathbf{v}$ & - \\
\hline$P$. cichorii & - & + & - & - & + & - & $d, v$ & - & - & $\mathbf{v}$ & $d, v$ \\
\hline $43,44,47,49-52,8717$ & - & - & - & - & + & - & - & + & + & + & - \\
\hline $35-40,42,45,46,48$ & - & - & - & - & + & - & - & + & + & + & + \\
\hline 41 & + & - & - & - & + & - & - & + & + & + & + \\
\hline 54 & - & + & - & - & + & - & - & - & - & - & - \\
\hline
\end{tabular}

a) Lelliott et al. $(1966)^{20)}$.

INAB と，徳島県産のチャ芽から分離した 1 菌株(No. 8717）は Pseudomonas に属した。Fig. 1 に示したよ うに本群の細菌も高い水核活性を有し，過冷却温度は -3C 付近であった。Table 3, 4 に示した細菌学的性 質からこの群の紐菌は次の 4 群に大別された。タイサ イから分離した No. 41 菌株の性質はP. syringae pv. syringae のそれに一致した。またワサビから分離した No. 54 菌株は P. cichorii に類似した一般性状を示し たが，蛍光色素非産生，デンブン非加水分解等の性質 で異なった。P. cichorii の水核活性についてはこれま で報告がないためキク斑点細菌病菌の 10 菌株 ${ }^{17)}$ ついて改めて氷核活性を調べたが，寸べて陰性であっ た。No. 41 扎よびNo. 54 を除く他の菌株はチロシン 加水分解性の有無によって二つの群に分けられたか， いずれるP. syringae pv. delphinium に相当する細菌 学的性質を示した。

これらの細菌はいずれもタパコに過敏感反応 (HR) を起こした。そこでNo. 54 菌株を除くこれらの細菌 をホウレンソウ，ダイコン，カブ，ハクサイ、キョウ ナ、キュウリおよびトマトに噴霧接種した結果，ハク サイ，カブ，およびダイコンの葉裹の表皮細胞に壊死 斑を多数生じ，とくに八クサイで顕著であった。これ は接種後湿室下で水浸状淡粶色を呈したが，のちに乾 噪して淡紫色に変色し，葉肉部が侵されることはなか った。有傷接種でも病斑の発達はみられなかったこと から，一種の HR と考えられた。また Delphinium spp. およびモクレンの葉に対してもまったく病原性 を示さなかった。しかし任意に選んた No. 22, 41，44， 45,49 および8717の6 菌株はライラック(白花)の葉 に対する接種試験でいずれる水浸状病斑を形成し，と くにNo. 41 菌株は強い病原性を示した。ワサビから 分離した No. 54 菌株は上記の各種野菜およびレタス
に対する付傷接種でまったく病原性を示さなかった。

\section{Erwinia 属稩菌}

$1978 \sim 80$ 年と 1987 年に静岡県下および香川県下て 採集したチャ芽から分離した Erwinia 属細菌並びに清 川がトウモロコシから分離した Erwinia 属細菌はいすず れも高い办核活性を示したか，静大保存菌株の $E$. herbicola 8 菌株とE. milletiae 5 菌株 ${ }^{13)}$ はいずれむ水 核活性を示さなかった。チャ芽から分離した菌株の細 菌学的性状はトウモロコシ菌株のそれと一致したが, いずれもチ+芽およびトウモロコシに対して病原性を 示さなかった。Erwinia属のINAB は菌株間でインド ール生成，メチルレッド反応，サッカローズからの遢 元物質の生成およびラフィノース利用性等の反応を異 にしたが，その他の主要な性質は $E$. ananas $^{21)}$ のそれ に一致した (Table 5, 6)。

\section{考察}

1978 80 年静岡鉸西部の茶園において，また 1987 年に香川県で鉢植えの幼木から分離された INAB は, 香川県の 1 菌株 (8717) を除き,すべて Erwinia ananas と同定された。一方，1986，1987 年の両年に静岡県中 部の茶園と徳島県の茶園で分離された INAB はその 大部分が Xanthomonas campestris と同定された。こ の事実は，地域やチャ樹の生育条件によって，チ+の 芽圈で生育する INAB の種類が大きく異なることを 示すものとして注目される。

E. ananas は日和見病原菌の一種で，通常は植物体 表面で生息するが，環境条件によっては植物組織を曼 して病気を起こす。病原菌としてはこれまでパイナy ブル心腐病 ${ }^{21)}$, イネ内穎褐変病 ${ }^{3}$, メロン果肉の裙 変40)の原因として報告されている。本細菌はイネでは 茥葉打よび穂に普遍的にみられる表生細菌として知ら 
Table 5. Bacteriological characteristics of the ice nucleation-active Erwinia

\begin{tabular}{|c|c|c|c|c|}
\hline (haracteristicsa) & $\begin{array}{c}\text { IN1-10, 12, } \\
13,15\end{array}$ & $\begin{array}{l}8703,8704 \\
8707-8712\end{array}$ & 53 & 55 \\
\hline Reducing substances from sucrose & $D^{(b)}$ & D & + & + \\
\hline Methyl red test & - & $\mathbf{D}$ & - & - \\
\hline Indole test & D & + & - & - \\
\hline DNase & D & D & \pm & + \\
\hline Hydrolysis of: Tween 80 & - & + & + & + \\
\hline esculin & + & D & + & - \\
\hline Growth at $40 \mathrm{C}$ & D & - & - & - \\
\hline Acid from: raffinose & D & + & + & + \\
\hline glycogen & - & - & - & - \\
\hline benzoate & + & + & - & + \\
\hline
\end{tabular}

a) All strains were positive for: straight rods; peritrichous flagella; yellow colonies; fermentative metabolism of glucose; production of catalase, $\mathrm{H}_{2} \mathrm{~S}$, acetoin; hydrolysis of casein ; gelatin liquefaction; growth at $35 \mathrm{C}$; growth inhibition by $\mathrm{KCN}$; ONPG; red, coagulation, peptonization and reduction of litmus milk; utilization of asparagine as a sole source of $\mathrm{N}$ and $\mathrm{C}$; utilization of L-arabinose, xylose, glucose, fructose, mannose, rhamnose, cellobiose, maltose, lactose, trehalose, melibiose, sucrose, sorbitol, inositol and salicin; use of formate, acetate, malate, fumarate, tartrate, malonate, oxalate, mesaconate, saccharate, propionate, caprate, caproate, quinate, anthranilate, mucate, glycolate, butyrate, maleinate, sebacate, benzoate, $p$-aminobenzoate and protocatechuate.

All strains were negative for: Gram reaction; spore formation; poly- $\beta$-hydroxybutyrate accumulation; production of oxidase, urease, arginine dihydrolase, tyrosinase, lecithinase, amino acid decarboxylases, phenylalanine deaminase, levan, 3-ketolactose; nitrate reduction; denitrification; gluconate test; hydrolysis of starch; pectate liquefaction; growth at $4 \mathrm{C}$; acid from erithrytol, adonitol, $\alpha$-methylglucoside, dulcitol, melezitose, inulin and xylan; potato rot; tobacco hypersensitivity reaction; and pathogenicity to tea.

b) For symbols see Table 2 .

Table 6. Comparison of the differential characteristics of the ice nucleation-active Erwinia strains to those of E. herbicola and E. ananasa)

\begin{tabular}{|c|c|c|c|c|c|c|}
\hline Characteristics & 53 & 55 & $\begin{array}{l}\text { IN1-10, } \\
12,13,15\end{array}$ & $\begin{array}{l}8703,8704 \\
8707-8712\end{array}$ & $E^{b} \mathbf{b}$ & $\mathrm{Ea}^{\mathrm{c})}$ \\
\hline Phenylalanine deaminase & $-d\rangle$ & - & - & - & + & - \\
\hline Indole test & - & - & D & + & - & + \\
\hline Reduction of $\mathrm{KNO}_{3}$ & - & - & - & - & + & - \\
\hline $\begin{array}{r}\text { Acid from: cellobiose, glycerol } \\
\text { inositol, melibiose }\end{array}$ & + & + & + & + & - & + \\
\hline Acid from: dulcitol & - & - & - & - & + & - \\
\hline
\end{tabular}

a) Bergey's Manual of Systematic Bacteriology, Vol. 1 (1984).

b) Erwinia herbicola.

c) Erwinia ananas.

d) For symbols see Table 2.

れている3゙。このためチャから分離された $E$. ananas は教わら等で茶園にすち込まれ，葉面で生息する形態 に入ったものが分離されたすのと考兄られなくるな い。そこで 1987 年早春一初夏に静岡県のイネわらを たは粐款を敷いた茶園からくり返し INAB の分離を 試みたが，Xanthomonas campestris 以外には分離で きなかった。一方, 香川県で E. ananas が分離された
鉢植党幼木では，付近にイネわらはまったくみられな かった。この事実は E. ananas がチ+樹の生育条件に よって，X. campestris と同様に安定した葉面で生息 する形態に入りらることる示唆している。このように $P$. syringae を含め 3 種の相異なる INAB が，それぞ れ別の地域または茶園から独立して分離されたこと がたんなる偶然かあるいはチ+樹の生理と何らかの 
因果関係を示すものであるかは與味あるところで, 非 水核活性細菌を利用した防霜戦略上からむ, 今後の研 笲淉題の一つとなろら。

チャの芽には通常 1 芽あたり $10^{6} \sim 10^{7}$ 個の細菌が 生息しているが，葉の展開とともに急減する。この細 菌の種類は地域, 時期を問わずほぼ一定しており, 白 色，黄色および橙色集落を形成する 数種の非虽光性 Pseudomonas（後藤・黄：未発表）に上って占められ ている。E. ananas 扰よび $X$. campestris の INAB は これら芽圈細菌の一棈成員と考えられるが，通常の分 離法による検出絬果に関する限り, 細菌集団中に占め る比率は一般に低く，しかもこれを保菌するチャ芽の 割合も低かった。しかしこの方法では，その検出精度 から $10^{3} \sim 10^{4}$ 細菌/芽以下の INAB の存在を否定す ることはできない。このよらな培養法による検出限界 以下の低密度 INAB の霜害に果たす役割は, その検 出方法とともに, チ十の霜害誘発源としての役割を検 討する上で, 今後重要な研究課題となろう。

Xanthomonas 属細菌で水核活性をむつものとして は,フロリダでカンキッ葉から分離された 1 例29) と $X$. campestris pv. translucens の一部菌株の例 ${ }^{18)}$ が知 られているのみである。前者は氷核活性を除くと非病 原性 X. campestris ${ }^{10)}$ の一般性状をわつといわれてい るが、チャ芽に存在する水核活性 $X$. campestris との 関係は現段階では明らかでない。著者らがチャ芽から 分離した水核活性 xanthomonad の性質は，X.campestrisのそれに一致したが，病原性は弱いジャガイモ 切片腐敗能を除いて認められなかった。このため本菌 の分類学的位固つけは，病原型よりむしろ亜種が適当 と考えられるが，学名については機会を改めて発表し たい。また静大保存菌株の $X$. campestris 15 pathovar について承核活性を調べた結果では，pv. theicola を 含む寸べてがこれを欠いていた。このことからもチャ 芽から分離された INA xanthomonad がきかめて特殊 な細菌であることがわかる。

一般緑葉野菜から INAB を分離した報告例は少な い。分離菌株数は比較的少ないか，今回野菜から $P$. syringae pv. syringae が高頻度で分離され，P. fluorescens, $P$. viridiflava, E. ananas, E. herbicola が分離さ れなかったことは注目される。Kaneda ${ }^{16)}$ はカナダで インゲンおよび Brassica napus の葉から分離される INAB がすべて P. fluorescens で，黄色 Erwinia はま ったく娭出されないことを報告し，Obata et al. ${ }^{31}$ む インゲン葉から办核活性をもった P. fuorescens を分
離している。Baca et al.4) はモクレンの花を含む木本 植物から分離した JNAB が大部分 $P$. syringae 群細菌 であり, P. fluorescens, E. herbicola の分麇頻度はわ ずかであることを報告している。これらの結果は，植 物と表生 INAB との間に一定の親和関保が存在する ことを示唆するものとして注目される。

ワサビから分離された No. 54 菌株の細菌学的性貿 は，LOPAT 試験20)などP. cichorii 17) のそれと共通す る点も多かったが，蛍光色素非産生，ガラクトースな ど数種榶類の非利用性, レシチナーゼ反応陰性等相違 点も多く認められた。本菌株はワサビの葉柄褐变部か ら分離されたが，ワサビ，八クサイ，カンラン，レタ ス等の葉片に対する接種ではいずれも病原性が認めら れなかった点から，P. cichorii とは異なる細菌と判定 した。その分類学的所属については改めて検討した W。

\section{摘要}

静岡県, 香川県および徳島県でチャ芽, 野菜および モクレンの花から分離した氷核活性細菌について分類 学的研究を行った。1978〜80 年静岡県で, 1987 年香 川県でチ+芽から分離した氷核活性細菌は，後者の 1 菌株を除きすへて Erwinia ananas と同定された。こ れに対し，1986 年および 1987 年の両年に静岡県で, また 1987 年に徳島県で分離された承核活性細菌は前 者の 1 菌株を除き, すべて Xanthomonas 属細菌であ った。この xanthomonad は最高生育温度等 2,3 の 性質を除き, 形態, 生理・生化学的性質から $X . \mathrm{cam}-$ pestris と同定されたが，チャをはじめ供試した数種野 菜には病原性を示さず，ジャガイモ切片をわずかに㜞 化したのみであった。この結果，本菌をX. campestris の新亚種と位置づけるのが妥当と考えた。タイサイ等 の緑葉野菜, チャ芽扰よびモクレンの花から分離した 氷核活性 pseudomonad はすべて Pseudomonas syringae と同じ細菌学的性質を示した。これらは分部 した植物，野菜類，Delphinium spp. に病原性を示さ なかったが，ライラックに対しては接種した菌株のす ペてが病原性を示したことから P. syringae pv. syringae と同定した。ワサビから分離した pseudomonad は P. cichorii に類似した性質を示したが，虽 光色素非産生, 非病原性等からこれとは異なる細菌と 判定した。これらの水核活性細菌は，いずれも高い米 核活性を示し，過冷却温度は $-2.8 \sim-3.0 \mathrm{C}$ にあっ たが，ワサビ菌株は -4C〜ー5Cであった。 


\section{引用文 献}

1. Andrews, P.K. and Proebsting, E.L., Jr. (1986). J. Am. Soc. Hortic. Sci. 111: 232-236.

2. Asworth, E.N. (1985). Ibid. 110: 287-291.

3. 畔上耕児・尾崎克己・松田 明・大畑貫一 (1983). 農技研報 C 37：1-12.

4. Baca, S., Canfield, M.L. and Moore, L.W. (1987). Plant Disease 71: 412-415.

5. Bradbury, J.F. (1987). Guide to Plant Pathogenic Bacteria. CAB Int. Myc. Inst. Kew, England.

6. Cody, Y.S., Gross, D.C., Proebsting, E.L., Jr. and Spotts, R.A. (1987). Phytopathology 77: 10361044.

7. Collins, M.D. (1985). In Methods in Microbiology (Gottschalk, G., ed.). Vol. 18. Acad. Press, New York. pp. 329-366.

8. Cowan, S.T. (1974). Cowan and Steel's Manual of the Identification of Medical Bacteria. 2nd ed. Camb. Univ. Press, Cambridge.

9. Dye, D.W. (1968). N. Z. J. Sci. 11: 590-607.

10. Gitaitis, R.D., Sasser, M.J., Beaver, K.W., McInnes, T.B. and Stall, R.F. (1987). Phytopathology 77: 611-615.

11. 後藤正夫 (1987). 今月の農業 31(10): 92-95.

12. 後藤正夫・稲葉忠興・後藤孝雄 (1987). 日植病報 $53: 408-409$ (满要).

13. 後藤正夫・高橋敏房・岡島徳岳 (1980). 同上 46: 185-192.

14. Gross, D.C., Cody, Y.S., Proebsting, E.L., Jr., Radamaker, G.K. and Spotts, R.A. (1983). Appl. Environm. Microbiol. 46: 1370-1379.

15. Gross, D.C., Proebsting, F.. L., Jr. and Andrews, P.K. (1984). J. Am. Soc. Hortic. Sci. 109: $375-380$.

16. Kaneda, T. (1986). Appl. Environm. Microbiol. 52: 173-178.

17. 川久保幸雄・後藤正夫 (1987). 日植病報 $53: 404$ (謱要).

18. Kim, H.K., Orser, C., Lindow, S.E. and Sands, D.C. (1987). Plant Disease 71 : 994-997.

19. King. E.O., Ward, M.K., and Raney, D.E. (1954). J. Lab. Clin. Med. 44: 301-307.

20. Lelliott, R.A., Billing, E. and Hayward, A.C. (1966). J. appl. Bact. 29: 470-489.

21. Lelliott, R.A. and Dickey, R.S. (1984). In Bergey's Manual of Systematic Bacteriology (Krieg, N.R. ed.). Vol. 1. Williams \& Wilkins, Baltimore. pp. 469-476.

22. Lindemann, J. and Suslow, T.W. (1987). Phytopathology 77: 882-886.

23. Lindow, S.E. (1982). In Phytopathogenic Prokaryotes (Mount, S.E. and Lacy, G.H. eds.). Vol. 1. Acad. Press, New York. pp. 335-362.

24. Lindow, S.E., Arny, D.C. and Unper, C.D. (1982). Phytopathology 68: 523-527.

25. 牧野孝宏 (1982). 日植病報 $48: 452-457$.

26. 牧野孝宏 (1983). 同上 $49: 32-37$.

27. Marmur, J. (1961). J. Mol. Biol. 3: 208-218.

28. Marmur, J. and Doty, P. (1962). Ibid. 5: 109-118.

29. Minsavage, G.V. and Stall, R.E. (1986). Proc. 6th Int. Conf. Plant Path. Bact., Maryland. pp. 994 1004.

30. 小幡 斉・谷下準一・中井剛史・徳山 泰 (1987). 日本農芸化学会昭和 62 年度大会講演要旨集 p. 374.

31. Obata, H., Saeki, Y., Tanishita, J., Tokuyama, T., Hori, H. and Higashi, Y. (1987). Agric. Biol. Chem. 51: 1761-1766.

32. Paton, A.M. (1959). Nature 183: 1812-1813.

33. Pauline, J.-P. and Juisetti, J. (1978). Proc. 4th Int. Conf. Plant Path. Bact. Vol. II, Angers. pp. 725731.

34. Pelczar, M.J., Jr. ed. (1957). Manual of Microbial Methods. McGraw-Hill Co., New York.

35. Phelps, P., Giddings, T.H., Prochoda, M. and Fall, R. (1986). J. Bacteriol. 167: 496-502.

36. Schaad, N.W. ed. (1980). Laboratory Guide for Identification of Plant Pathogenic Bacteria. American Phytopathological Society, St. Paul.

37. 白田 昭・後藤正夫 (1981). 植物防疫 35: 325-326.

38. 高檽幸吉 (1985). 同上 $39: 8-13$.

39. 植原一雄・荒井 啓・野中寿之・佐野岩男 (1980). 鹿児島大農学報 30：17-20.

40. Wells, J.M., Sheng, W.-S., Ceponis, M.J. and Chen, T.A. (1987). Phytopathology 77: 511-514. 